\title{
SSynthesis
}

International Scientific Conference of IT and Business-Related Research

\section{UČENJE ENGLESKOG JEZIKA STRUKE U VISOKOŠKOLSKIM USTANOVAMA U SRBIJI: METODE, SAVETI I PRIMERI}

\author{
LEARNING ENGLISH FOR SPECIFIC PURPOSES IN HIGHER EDUCATION \\ INSTITUTIONS IN SERBIA: METHODS, RECOMMENDATIONS, EXAMPLES
}

\author{
Tamara Stefanović, Vanja Vukčević, Ana Kažanegra-Veličković, Vesna Jokanović \\ Beogradska poslovna škola-Visoka škola strukovnih studija, Kraljice Marije 73, Beograd, Srbija
}

\begin{abstract}
Apstrakt:
U doba globalizacije poznavanje engleskog jezika predstavlja jedan od glavnih preduslova za razvoj ljudskih resursa, a napredni nivo znanja engleskog jezika struke smatra se neophodnom veštinom mladog visoko-obrazovanog čoveka u modernom poslovnom svetu. Savremena istraživanja pokazuju da se poznavanje engleskog jezika struke postavlja danas kao imperativ profesionalnog opstanka, kako pojedinca tako i samog društva. Akademska zajednica, koja obrazuje stručni kadar, ima veliku odgovornost u obezbeđivanju uslova za sticanje najnovijih znanja kako iz oblasti modernih tehnologija, tako i iz oblasti stranog jezika stuke, kao dveju suštinski neizostavnih oblasti za razvoj privrede i industrije jedne zemlje. Ovaj rad pruža konkretan uvid u razvoj i trenutno stanje nastave engleskog jezika struke u visokoškolskim ustanovama u Srbiji, uz metode, koncepte i savete koji se mogu primenjivati u nastavi engleskog jezika u funkciji struke. Analizom metoda i praktičnih iskustava opisanih u radu, dolazi se do zaključka da kod učenja stranog jezika struke, naglasak treba da bude na raznovrsnosti metoda, na stalnom izlaganju jeziku, kao i na čestom korišćenju autentičnih materijala, zadatka i aktivnosti koje simulišu situacije u kojima će se naći budući stručni kadrovi.
\end{abstract}

\section{Ključne reči:}

engleski jezik struke, stručni kadar, znanje, nastavni proces, metode.

\section{UVOD}

Savremeni pristup učenju jezika ima naučnu osnovu kojoj doprinose brojne discipline, a među njima najznačajnije su: filologija, psihologija i pedagogija. Brojni činioci utiču na kvalitet učenja stranih jezika i nastavnih metoda. U procesu učenja stranog jezika posebnu pažnju treba obratiti na raznovrsnost nastavnih metoda i stepen izloženosti jeziku. Raznovrsnost je neophodna kako bi se savladali različiti aspekti jezika, ali i da bi se izbegla monotonija. Za učenje stranog jezika ne postoji jedinstveni metod, već je nastavnik onaj koji planira nastavni proces jezičkih aktivnosti, uzmajući u obzir individualne karakteristike učenika, kao što su uzrast, profil, lične karakteristike i potrebe, a koje zavise od socijalnog i kulturnog okruženja. Različitost društvenih situacija, kulturnih okruženja i individualnih karakteristika korisnika jezika jedan je od osnovnih postulata komunikativne nastave stranih jezika. Drugim rečima, kulturni kontekst je od presudnog značaja u oblikovanju govornikove komunikativne kompetencije, kako u prvom/maternjem, tako i u svim drugim jezicima koje uči. Dakle, učenicima/studentima stranog jezika potrebno je obezbediti i socio-kulturni kontekst

\section{Abstract:}

In the era of globalization, the knowledge of English language is considered one of the main preconditions for the development of human resources, while the advanced level of English for specific purposes is considered an essential skill of a young highly-educated man in the contemporary business world. Modern research shows that the knowledge of English for specific purposes is set today as a professional imperative of survival of an individual, as well as the society itself. The academic community, which educates professional staff, has a great responsibility in ensuring the conditions for acquiring the latest knowledge in the field of modern technologies and LSP, regarding the fact that these two are fundamentally indispensable for the development of the economy and industry of a country. This paper provides the specific insight into the development and the current state of the process of teaching English for specific purposes in higher education institutions in Serbia, along with methods, concepts and recommendations that can be used in teaching English for specific purposes. By the analysis of methods and practical experiences described in this paper, one comes to the conclusion that when learning a foreign language for specific purposes, the emphasis should be placed on a variety of methods, the constant exposure to a language, as well as the frequent use of authentic materials, tasks and activities that simulate situations that future professional staff shall encounter.

\section{Key words:}

English for specific purposes, professional staff, knowledge, teaching process, methods.

u kome se taj jezik govori, kao i pratiti i zadovoljavati njihova lična interesovanja i potrebe.

\section{DISKUSIJA}

\subsection{JEZIK STRUKE I NJEGOVE KARAKTERISTIKE}

Naše društvo nalazi se u eri globalizacije, intenzivnog razvoja elektronike i telekomunikacija. U svakodnevnom govoru koriste se termini engleskog porekla ( $P C$, display, monitor, email, download, itd.) koji su se odomaćili u srpskom jeziku, a za pojedine reči nema ni adekvatnog pevoda na naš jezik, te je neophodno da svaki budući poslovni čovek tečno govori engleski jezik, kako „opšti“, tako i svoje struke, bez potrebe za angažovanjem prevodioca za isti.

Strani jezik struke postao je značajna oblast ne samo u domenu obrazovanja, već i ekonomije i poslovnih komunikacija uopšte. Ono što je karakteristično za jezik struke jeste specijalizovan vokabular, a to znači da svako polje ima specifičnu terminologiju, pri čemu pojedine reči iz svakodnevnog života imaju drugačije značenje u određenoj stručnoj oblasti (Ignjačević, 2012). 
Prema jednom od najznačajnijih autora iz oblasti engleskog jezika struke, Toniju Dadli-Evansu, jezik struke moguće je opisati nizom karakteristika. Kao apsolutne karakteristike DadliEvans i Sent Džon (1998) navode sledeće:

1. Jezik struke je definisan tako da odgovori na specifične potrebe učenika.

2. Jezik struke koristi postojeću metodologiju i aktivnosti discipline kojoj služi.

3. Jezik struke je usmeren na jezik koji je odgovarajući za te aktivnosti u smislu gramatike, leksike, registra, veština učenja, diskursa i žanra.

Iako se, teorijski gledano, jezik struke kao jezički sistem ne razlikuje od opšteg jezika ni po čemu sem po terminološkoj leksici, nastava stranog jezika struke se donekle razlikuje od nastave stranog jezika za opšte potrebe. Ta razlika se prvenstveno ogleda u tome što kombinuje nastavu struke i nastavu jezika, u odgovarajućem kontekstu. Ukoliko se nastava jezika struke odvija u akademskom okruženju, osim znanja i veština jezika i struke, potrebno je razvijati i akademsku jezičku kompetenciju kako na stranom, tako i na maternjem jeziku.

\subsection{UČENJE ENGLESKOG JEZIKA STRUKE NA VISOKIM ŠKOLAMA STRUKOVNIH STUDIJA U SRBIJI}

Nastava stanih jezika je organizovan proces, čiji su ciljevi utvrđeni u skladu sa opštom vaspitno-obrazovnom politikom našeg društva i aktuelnim zadacima (Đorović, 2004).

Sa stanovišta teorija učenja, možemo govoriti o opštem zaokretu od kognitivnih i razvojnih teorija ka konceptu socijalnog učenja kroz saradnju. Dakle, možemo govoriti o holističkoj nastavi stranih jezika, koja je usmerena na socijalnu interakciju, koja u mnogome unapređuje kvantitet jezičkog materijala koji je neophodan uslov za bilo koje učenje jezika.

Nastava stranih jezika, kroz primenu Bolonjske deklaracije, bazira se na shvatanju jezika kao sredstava komunikacije, odnosno kao društvenog oruđa koje govornici koriste da prenesu značenje. Stoga, treba istaći da se strani jezik u učionici ne pojavljuje kao nekakav izolovan fenomen kome se posvećujemo kroz duga i, manje ili više, teorijska objašnjenja na maternjem jeziku učenika, već kao sistem koji studenti treba da prepoznaju kao funkcionalan medijum za primanje i prenošenje informacija koje su od značaja za proširenje njihovog sistema znanja.

$\mathrm{U}$ istraživanju smo krenule od uporedne analize nastavnih programa za engleski jezik na više raznorodnih visokoobrazovnih institucija koje školuju kadrove za rad u različitim poslovnim i IT oblastima. Detaljnom obradom pomenutih programa uočena je ozbiljnost pristupu izučavanja engleskog jezika struke na studijama. Kroz nastavne planove se vidi da se na većini visokoškolskih ustanova ovaj jezik uči skoro na svim godinama studija, što ga svrstava u red osnovnih predmeta studijama, jer se u savremenom poslovnom svetu ne može zamislliti rad bez aktivnog znanja engleskog jezika.

Nastavnim planom Beogradske poslovne škole - Visoke škole strukovnih studija predviđeno je da se engleski jezik uči kao obavezni na prvoj i drugoj godini. Engleski I se izučava jedan semestar i pokriva „opšti“ engleski jezik i osnovne gramatičke strukture i leksičke i frazeološke jedinice, tj. bazira se na upotrebi engleskog jezika u svakodnevnim životnim situacijama. Engleski jezik II, tzv. Poslovni engleski, izučava se na drugoj godini studija u trajanju od dva semestra. Program obuhvata pažljivo birane nastavne jedinice sa tekstovima za obradu stručnih tema iz oblasti poslovnog engleskog jezika, vezanih za oblasti finansija, računovodstva i bankarstva, poslovne informatike, menadžmenta i poreza i carina, kao i osnovne i složene gramatičke strukture. Kako je u nastavi engleskog jezika glavni cilj razvijanje komunikativne sposobnosti posebno na poslovnom nivou, veoma je važno obratiti posebnu pažnju na nastavu pismenog izražavanja. Imajući ovo u vidu, deo nastavnog programa akcenat stavlja na pismenu korespodenciju: pravila i primeri za pisanje biografije i propratnog pisma, zvaničnog i neformalnog pisma, prijave za posao, zahteva za nabavku, itd.

U Beogradskoj poslovnoj školi nastava se odvija u manjim grupama, kada su u pitanju vežbe, a u većim kada su u pitanju predavanja. Studenti su se putem ankete sprovedene 2014. godine na smeru Finansije, računovodstvo i bankarstvo većinom izjasnili da im najviše odgovara rad u malim grupama i parovima, a da im ne prija rad u velikim grupama. Što se tiče nastavnih metoda, studenti se izjašnjavaju za grupni rad, prezentacije i rad u paru, jer će im to koristiti u budućem radu, a stavljanje studenta u konkretne i realne poslovne situacije pomaže mu da uvežba ne samo jezik struke i pravilnu upotrebu gramatičkih struktura, već uči da savlada tremu i da radi na vizuelnom predstavljanju.

Takođe, kada je reč o nastavi u Beogradskoj poslovnoj školi, treba istaći da studenti nisu toliko često izloženi autentičnim audio-materijalima, jer su grupe vrlo brojne, te se nastava može lako ometati, a to bi dovelo do neuspešno izvršene aktivnosti. Čitanje predstavlja važnu sposobnost koju treba razvijati u nastavi, a da bi se pospešila ova veština, studentima se pruža mogućnost korišćenja autentičnih tekstova koji zadovoljavaju specifične potrebe studija, uz dodatak zanimljivih zadataka koji se tiču razumevanja tekstova, a koji istovremeno podstiču kreativno i kritičko razmišljanje u pozitivnoj radnoj atmosferi (Nunan, 2003).

Nastavnim planom Visoke poslovne škole u Blacu predviđeno je da se engleski jezika uči na svim godinama studija kao jednosemestralni predmet. Engleski I predstavlja kompletan prvi kurs poslovnog engleskog jezika koji sistematski pokriva sve osnovne jezičke strukture. Kroz dvanaest nastavnih jedinica sastavljenih od autentičnih tekstova obrađene su sve četiri veštine: čitanje, pisanje, slušanje i govorenje. Engleski II je baziran na pažljivo sastavljenom jezičkom programu, sa petnaest nastavnih jedinica koje obuhvataju ključne oblasti poslovne interakcije, kao što je telefoniranje, sastanci i druženja. Ovim kursom je obuhvaćen prošireni program izgovora i vokabulara, kao i materijala za slušanje. Engleski III je baziran na razumevanju jezika što je razrađeno kroz sadržaj svakodnevnog poslovnog rečnika. Četrnaest nastavnih jedinica pružaju mogućnost za vežbanje jezičkih veština kroz specifične i opšte situacije. Ostale karakteristike kursa su: dosledno korišćenje autentičnog materijala iz stvarnih kompanija, rečnik poslovnih termina i kompletna gramatika.

$\mathrm{Na}$ Visokoj elektrotehničkoj školi u Beogradu nastavni plan predviđa Engleski I u prvom semestru i Engleski II u šestom semestru. Engleski I za cilj ima da studenti steknu osnovna znanja iz engleskog jezika neophodna za osnovnu komunikaciju, kako bi uspešno pratili nastavu iz Engleskog jezika II. Engleski II za cilj ima da se studenti osposobe da komuniciraju na engleskom jeziku i da se služe kako opštim, tako i stručnim engleskim jezikom.

Uporednom analizom prethodno navedenih nastavnih programa jasno se dolazi do saznanja da je izučavanje engleskog jezika ozbiljno postavljeno skoro na svim poslovnim i IT studijama.

S obzirom da je predmet ovog rada učenje engleskog jezika struke, možemo da kažemo da je u zadovoljavajućem odnosu zastupljen na svim pomenutim institucijama, negde sa manjim, a negde sa većim nedeljnim fondom časova. Sličan broj časova imaju Beogradska poslovna škola i Visoka poslovna škola iz Blaca, gde se engleski jezik struke uči po dva semestra, s tim što se u BPŠ izučava kao dvosemestralni predmet na drugoj godini, a u Blacu kao jednosemstralni na II i III godini. Najmanja zastupljenost je na Višoj elektrotehničkoj školi iz Beograda gde se engleski jezik struke izučava samo u šestom semestru studija. Smatramo da engleski treba da bude zastupljen na svim 
godinama studija, a da se od druge godine do kraja studija u svakom semestru izučava kao jezik struke. Takođe, za one studente koji u prethodnom školovanju nisu učili ovaj strani jezik treba da se organizuje dodatna nastava, s obzirom da i dalje ima sredina u kojima se ovaj jezik ne uči, kao i da se kod studenata razvije svest da se njihov rad ne može zamisliti bez poznavanja engleskog jezika uopšte. Treba ih motivisati da shvate da im je engleski jezik za specifične namene bitan u poslovnom svetu skoro isto koliko i maternji. Mišljenja smo da se pored engleskog jezika struke u nastavni plan treba uvrstiti i drugi strani jezik struke, koji će student po svom interesovanju izabrati da uči.

\section{REZIME}

Pre dva veka obrazovanje u Srbiji se razvijalo na talasima prosvetiteljstva oblikovanog naučnim napretkom i nastajućom industrijskom revolucijom. Danas se obrazovanje u Srbiji susreće sa brojnim izazovima naučnog, humanističkog, socijalnog i drugog razvoja; sa velikim tehnološkim promenama, pravim revolucijama; sa globalizacijom i opštom mobilnošću svega što se može kretati, od kapitala do kulturnih obrazaca. Sistem obrazovanja je prvi i najvažniji elemenat životne i razvojne infrastrukture svakog pojedinca, društva i države, jer njegov ukupan efekat određuje kvalitet i efekte izgradnje i korišćenja svih drugih sistema, resursa i kvaliteta života. Stoga, sistem obrazovanja treba da se razvija tako da svoju ulogu ostvaruje pravovremeno, kvalitetno i efikasno. Potpuno se treba prihvatiti uloga koju obrazovanje mora imati u ekonomskom, kulturnom, socijalnom, političkom, demokratskom i drugom razvoju i poboljšanju strateškog, kooperativnog i konkurentnog kapaciteta i položaja Srbije u savremenom svetu, posebno u Evropskoj uniji.

Imajući u vidu sve navedeno, jasno je da Engleski jezik struke predstavlja važno sredstvo u procesu internacionalizacije visokog obrazovanja i obrazovnih procesa, a da su profesori ti koji imaju zadatak da na što efektivniji način omoguće studentima da steknu osnovno znanje stranog jezika koje im obezbeđuje aktivno učešće u diskusijama, na naučnim konferencijama i seminarima, kao i mogućnost samostalnog čitanja stručne literature. Cilj svim profesorima na strukovnim, ali i akademski studijama, treba da bude da studente motivišu da se aktivno uključe u nastavni proces učenja stranog jezika, kroz metodu interaktivne nastave, što je u skladu sa komunikativnim pristupom učenju stranih jezika. Zadatak visokih škola strukovnih studija jeste upravo taj da kroz sistem dualnog obrazovanja (teorija i praksa) studente pripreme i osposobe za rad. Analogno tome, rukovodstva ovakvih škola moraju uvideti i istaći značaj engleskog jezika struke, kao osnovnog „oruđa“ za rad jednog poslovnog, mladog čoveka u modernom svetu nauke i poslovanja.

\section{LITERATURA}

Basta, J. (2012). Strani jezik struke u visokom školstvu. Filologija i univerzitet: tematski zbornik radova, str. 787-801. Preuzeto 1. Marta 2015. sa http://www.filfak.ni.ac.rs/izdavastvo/ index.php?option $=$ com_k2\&view $=$ item\&task $=$ download $\&$ $\mathrm{id}=350 \_198 \mathrm{~d} 82 \mathrm{ffb} 227 \mathrm{bce} 3 \mathrm{af} 7 \mathrm{a} 75 \mathrm{efe} 157 \mathrm{f03b} \&$ Itemid $=152$

Dudley-Evans, T., \& St John, M.J. (1998). Developments in ESP: A multi-disciplinary approach. Cambridge: Cambridge University Press.

Đorović, D. (2004). Odnos studenata humanističkih nauka prema stranim jezicima. Nastava i vaspitanje, 53(4-5), 448-464.

Hedge, T. (2000). Teaching and Learning in the Language Classroom. Oxford: Oxford University Press.

Ignjačević, A. (2012). Strani jezik u funkciji struke: nastava i učenje. Beograd: Filozofski fakultet.

Maksimović, J., \& Osmanović, J. (2013). Stavovi studenata društvenih i humanističkih nauka o proučavanju stranih jezika. Philologia Mediana, str. 443-460. Niš: Filozofski fakultet.

Mišić-Ilić, B. (2011). Nastava jezika struke kao sinergija znanja jezika i struke. Niš: Filozofski fakultet.

Nunan, D. (2003). Practical English Language Teaching. New York: McGraw-Hill

Tarabar, A. (2014). Načini i mogućnosti istovremenog učenja engleskog jezika i stručnog gradiva u nastavi iz oblasti održavanje. Univerzitet u Zenici, BiH

Vlada Republike Srbije Ministarstvo prosvete i nauke. (2011). Strategija razvoja obrazovanja u Srbiji do 2020. godine. Preuzeto 5. marta 2015. sa http://www.kg.ac.rs/doc/strategija_obrazovanja_do_2020.pdf

Vranješević, J. (2012). Budućnost nastavničke profesije: kompetentni pojedinci u kompetentnom sistemu. Stručni seminar Centra za obrazovne politike: Promene u akademskoj i nastavničkoj profesiji. 